\title{
A Study on APEC's Economic Cooperations under WTO
}

\author{
Dr. Jae-Sung, Lee \\ Visiting Professor, New Jersey City University, USA \\ E-mail: jslee797@yahoo.co.kr
}

Received: September 4, 2012

Accepted: October 15, $2012 \quad$ Online Published: October 26, 2012

doi:10.5430/ijba.v3n6p55

URL: http://dx.doi.org/10.5430/ijba.v3n6p55

\begin{abstract}
The changes in the international economic order are posing new challenges to the Asia-Pacific countries. To adapt to the WTO system and APEC, they must change their basic pattern of economic policy in relation to industry, finance and other areas, such as labor standards and competition policy.

Government policy, however, is not the only, or even the major area facing new challenges. It will be the firms that will have to bear the brunt of the burden of adapting to the new environment. Moreover, the new global economic order no doubt means intensified competition, and it is the firms that compete. In order to survive in the new environment, they must be ready to undergo drastic changes, e.g. strategic alliances beyond national borders. This paper examines how to cooperate each other under APEC \& WTO system to realize foreign open policy and to encourage the developing countries to be grow market orient.
\end{abstract}

Keywords: APEC, Regional economic cooperation, WTO, Firms, Competition, Environment

\section{Introduction}

APEC could be important by providing a mechanism to defuse U.S.-Japan rivalry in the Asia-Pacific, deal with issues of a substantial regional component such as exchange rate management and most importantly, to secure increased market access in Asia which is the economic and political counterweight to increased import penetration in manufacturing. To become a successful organization, APEC will have to confront and resolve the issues of intra-APEC diversity as well as the treatment of non-members. It has been understood difficult for the Asia-Pacific countries to achieve economic cooperations among them due to the differences in the factors such as the development stage, political system, cultural tradition and so on. However, for the last 20 years, economic integration in the region has been under way through the deepening of the mutual dependence by sustaining high rates of growth. Compared with the institutional economic integrations of the BU and NAFTA, the economic integration in the Asia-Pacific region is often called a market-oriented economic integration. Since the founding in 1989, APEC has been developed into a major economic organization in the region experiencing six annual meetings. The results of the APEC meetings in the periods can be summarized as the organization of the subcommittees and cooperation projects, expansion of member countries, and the active execution of regional economic cooperations. Especially, APEC is known to have played an important role in inaugurating WTO by ending the UR negotiations that lasted past eight years. (Note 1)

The APEC meeting held in Seattle in November1993 provided a turning point for the advancement in Asia-Pacific economic cooperation. Firstly, the founding of CTI (Committee on Trades and Investments) made a chance of transforming APEC in the form of a loose association into a practical organization for economic cooperations, Secondly, as the formal meetings for ministers of finance, and of environment are agreed on, the economic cooperations in the future will not be confined to trade, investment and technological transfer. The cooperation between the Asia-Pacific countries will cover broad areas of macroeconomic policy coordination, environment, security, and culture. Thirdly, the realization of policy coordination will provide a solution to the conflict among member countries caused by the protectionism of the U.S. and the hindrance of Japan to the foreign access of Japanese market. The success of APEC in the future as an economic integration depends externally on the establishment of leadership and coordination power in fortifying the WTO while restraining the closed bloc of the EU, and internally in unifying the regional economies of east Asia and north America with NAFTA at the hub. The purpose of this study is to suggest way in developing APEC into a more open regional economic integration in the international trade order of the WTO. 


\section{Economic Policies in APEC}

Table 1 shows the evolution of key players in global trade, defined as countries whose trade (exports plus imports) represented at least 2 percent of world trade. In the early 1970s, trade was largely confined to a handful of advanced economies, notably the United States, Germany, and Japan, which together accounted for more than a third of global trade. By 1990, the global trading landscape had become more diversified to

include several EMEs, especially in East Asia. By 2010, China became the second largest trading partner after the United States, overtaking Germany and Japan. China's emergence reflects its rapid industrialization process and growing trade openness; trade was 57 percent of GDP in 2008 in China - almost triple the ratio of the United States.

Now, we compare the figures of GDP, population, per capita GDP of the APEC countries. As reported in Table 2, the total GDP of U.S. is about 6 trillion dollars and that of Japan 3.7 trillion dollar respectively as the two major economic forces in economic scale. Next come Canada, China and Mexico with GDP of 0.55 trillion dollars, 0.44 trillion dollars and 0.33 trillion dollars respectively. Korea, Australia, Taiwan, Indonesia, Hong Kong are making a group of countries with GDP in the range of 0.1 to 0.3 trillion dollars. While, Brunei and Papua New Guinea produced the GDP smaller than 10 trillion dollars showing large gaps compared to other member countries. In per capita GDP as of 1992, Japan is about 30 thousand dollars, the U.S. 23 thousand, Canada 20 thousand. The countries with per capita GDP over 10 thousand dollars are Singapore, Hong Kong, Australia, New Zealand, Brunei and Taiwan. China and Indonesia remained at the lower level of 3.7 hundred dollars and 5.9 hundred dollars. In population, China has the population of 1.2 billion and Mexico 0.09 billion. The countries with small population are Brunei and Singapore with population 280 thousand and 2.8 million respectively.

\section{Sub-regional Cooperations}

Formation of NAFTA does not mean that the U. S. has abandoned multilateralism or downsized its role as a global player. It is important to recognize that the U.S. sees NAFTA as an integral part of a greater, global strategy. NAFTA is seen in the U.S. essentially as a means of increasing U.S. exports. Regionalism is viewed in North America as a supplement, not substitute, for globalism. Economic regionalism has little appeal for East Asia which has benefited much from the multilateral trading system. This is especially true for Northeast Asia, and the regionalism that exists in Southeast Asia gives primacy to extra-regional economic ties. East Asia prefers informal integration of the region through market forces.

Asia-Pacific countries are unlikely to organize themselves into a trade bloc. They will instead be committed to the principle of globalism, which is no doubt the first-best option. It is in their interest, however, to see that APEC grow stronger as a forum that would facilitate trade and investment flows in a non-discriminatory fashion, help solve problems, diffuse tension and provide inputs for policy making.

The emergence of APEC has reduced various regional groupings in the Pacific basin into sub-regional entities. APEC cannot obviate the need for sub-regional arrangements, not only because APEC is too big, too unwieldy or too heterogeneous but also because each sub-region has its own problems that call for sub-regional solutions.

Additionally, the emergence of sub-regional economic zones in the Asia-Pacific over the past few years can be largely explained by the shifting comparative advantage and changing industrial structure in many economies in the region. It has become necessary for them to relocate industries to other lower-cost production bases in the context of the 'flying-geese' pattern of industrial development. Economic reform and open-door policy in the socialist countries in the region have provided more opportunities for the expansion of frontiers.

The Northeast Asian region is characterized by heterogeneity among the economies and relative skewness of economic relations. Most importantly, the Northeast Asian economies are complementary with one another in terms of industrial structure, resource endowment, and technology. This complementarity is the most important source of inter-industry cooperation in Northeast Asia. The diversity in the levels of economic development among the countries in the region also provides opportunities for economic cooperation. However, economic relations between countries at different levels of development often result in structural imbalances. A lack of mutual understanding due to a long history of ideological confrontations and different economic systems also pose a constraint to cooperation in the region. The development of economic relations in Northeast Asia is currently motivated by profits and pressure at a microeconomic level. Since the Northeast Asian economies have a great potential for industrial development and trade growth, relations are expected to expand. Trade and investment flows among China, Japan and Korea will no doubt be the most dynamic element. There is a dispute settlement procedures in Canada-U.S. trade. We also can see the record of dispute panels between Canada and the U.S., including those concerning Canada's export of beer, softwood lumber and live swine. 
Dispute settlement procedures are the key to solving trade issues under the new WTO system. WTO will surely work out a better definition of the dispute settlement mechanism, which could be applied to the trilateral trade relations within NAFTA.

The success of the dispute settlement procedures, however, depends heavily on the creation of new institutions to monitor and enforce decisions. Federal nation states such as Canada represent special problems in this context because of the shared jurisdiction over trade-related issues.

\section{Strategic Alliance by Firms}

The changing role of Asian NIE-based firms in forming strategic technology alliance with multinational corporations. We can analyzes cases of strategic alliances for technology involving Korean firms across seven industries, with an emphasis on finding different types of complementary assets that Korean and U.S. firms have and on the changing role of Korean firms in forming strategic alliance with U.S. firms.

We finds that, notwithstanding the differences across industries, the role of Korean firms, especially in high-tech industries, is changing from subcontractor to partner. Korean firms in microelectronics and consumer electronics, for example, now possess the capability to manufacture major parts as well as process technology. These complementary competitive advantages enable Korean firms to become partners in forming strategic technology alliances. But, in order to become real partners in the future, Korean firms must develop their own distinctive area of technological competence. Economic cooperation in the Asia-Pacific can offer a cornerstone of trust which would lead to a successful partnership among firms in this region. In addition, economic cooperation will help create one of the largest markets where competition will undoubtedly be intense. In an environment of fierce competition, firms cannot remain ahead without sustaining technological leadership, which requires not only joint technology development but also exchanges of complementary technology. Since technological convergence requires technologies from diverse industries, firms in the Asia-Pacific should consider ways to effectively combine their core competences through economic cooperation..

\section{Conclusion}

Now, we focus on the future agenda of the WTO system, namely the environment and competition policy; With the completion of the Uruguay Round, the next priority agenda will be the trade-environment issue. The WTO has in fact established a formal committee to prepare for this issue, and much of the work is expected to be based on the results of the long-term studies and debates in the OECD. However, serious discussion has yet to begin at the regional level. This is particularly true for the economies in the Asia-Pacific region, even though it remains most vulnerable in terms of the environmental problems. Combining economic dynamism with effective management of the environment is a critical challenge for the countries in the region. To be sure, the gap between the views of the developed and the developing countries remains large. When linking trade and the environment, there is substantial differences of opinion depending on whether the issue is viewed from the trade perspective or the perspective of the environment. Nevertheless, it is believed that in order to effectively deal with the problem of burden sharing, international cooperation in trade-environment must be based on the understanding of the disparities among the economies. The world trading system must, in particular, be able to support sustained development, for only then will countries be able to cope with environmental issues. To this end, it is suggested a basic fact-finding regional study so as to gain an independent understanding of the issues from the perspective of Asia-Pacific.

As traditional trade barriers are lowered and globalization progresses, markets are becoming increasingly integrated and competition stiffer. This poses significant competition-related problems, including inadequate enforcement or non-existence of national competition laws, differences in competition laws across countries, abuse of global market power, and conflicts between anti-dumping and competition rules. These problems call for a unified and substantive international approach to competition policy. Such an approach is necessary to ensure 'fair trade' or an 'equality of competitive opportunities between foreign and domestic firms. The crucial question is how to identify problems, tensions and opportunities that present themselves in the context of the world competition/trading system, and to formulate a more narrowly focused agenda in response. Although a substantial progress has been achieved on the old GATT issues in the Uruguay Round, there still remains unresolved areas which will continue to limit the contestability of markets, In particular, there is the danger of utilizing anti-dumping measures to restrict imports of specific products. Market-opening issues, extraterritorial enforcement, and exploitative and discriminatory state actions must also be addressed.

\section{References}

Ahmed, Shagil. (2009). Are Chinese Exports Sensitive to Changes in the Exchange Rate? International Finance 
Discussion Papers No. 987 (Washington DC: Board of Governors of the Federal Reserve System).

Blanchard, Olivier, \& Gian Maria Milesi-Ferretti. (2009). Global Imbalances: In Midstream? IMF Staff Position Note 09/29 (Washington: International Monetary Fund).

Brenton, Paul, Christian Saborowski, Cornelia Staritz, \& Erik von Uexkull. (2009). Assessing the Adjustment Implications of Trade Policy Using TRIST. Forthcoming in World Trade Review, ed. by Winters (Geneva: World Trade Organization).

Broda, Christian, \& David Weinstein. (2006, May). Globalization and the Gains from Variety. Quarterly Journal of Economics, 541-585.

Chen, Hogan. M., Matthew Kondratowicz, \& Kei-Mu Yi. (2005). Vertical Specialization and Three Factors about U.S. International Trade. North American Journal of Economics and Finance, 16(1), 35-59.

Crozet, Matthieu, \& Pamina Koening. (2010). Structural Gravity Equations with Intensive and Extensive Margins. Canadian Journal of Economics, 43(1), 41-62.

Daudin, Guillaume, Christine Rifflart, \& Danielle Schweisguth. (2009). Who Produces for Whom in the World Economy? OFCE Working Paper, July.

Dedrick, Jason, Kenneth Kreamer, \& Greg Linden. (2010). Who Profits from Innovations in Global Value Chains: A Study of the iPod and Notebook PCs. Industrial and Corporate Change, 19(1), 81-116.

Freund, Caroline. (2009). The Trade Response to Global Downturns: Historical Evidence. World Bank Policy Research Paper 5015, August.

Gagnon, Joseph E. (2007). Productive Capacity, Product Varieties, and the Elasticities Approach to the Trade Balance. Review of International Economics, 15(4), 639-659.

Gaulier, Guillaume, Françoise, Lemoine, \& Deniz Ünal-Kesenci. (2009). China's Integration in East Asia: Production Sharing, FDI and High-Tech Trade. Working Paper No 2005-09, June.

Hausmann, Ricardo, Jason, Hwang, \& Dani, Rodrik. (2007). What You Export Matters. Journal of Economic Growth, 12, 1-25.

\section{Note}

Note 1. William E. James. "Toward Free Trade in the APEC Region: Facilitation and Liberalization Option," KIEP International Seminar Paper on APEC, Oct. 2009, Seoul Korea. P.1. 
Table 1. Exports of key players in international trade

(Percent of world trade)

\begin{tabular}{|c|c|c|c|c|c|c|c|c|c|c|c|c|c|c|c|c|c|}
\hline & USA & Switzerland & Singapore & Saudi Arabia & Mexico & Korea & Japall & $\mathbb{E}$ & Chima & Canda & England & Sweden & Netherland & Italy & Germany & France & Belgium \\
\hline 1970 & 4.3 & 0 & 0 & 0.2 & 0 & 0.09 & 1.8 & 0.2 & 0 & 1.6 & 1.9 & 0.7 & 1.2 & 1.3 & 3.35 & 1.76 & 1.1 \\
\hline 1990 & 3.2 & 0.6 & 0.4 & 0.4 & 0.2 & 0.5 & 2.4 & 0.7 & 0.5 & 1 & 1.5 & 0.4 & 1.11 & 1.4 & 3.4 & 1.75 & 0.9 \\
\hline 2010 & 2.4 & 0.3 & 0.6 & 0.5 & 0.6 & 0.8 & 1.4 & 0.72 & 2.9 & 0.8 & 0.8 & 0.25 & 1.1. & 1.5 & 2.2 & 0.95 & 0.8 \\
\hline
\end{tabular}

Source: Direction of Trade Statistics, IMF 2012

Table 2. Major economic indicators of APEC countries

\begin{tabular}{|l|l|l|l|}
\hline Classification & Population(million) & GDP(million dollars) & Per capita GDP(dollar) \\
\hline NAFTA & 369.67 & $6,845.5$ & 18,518 \\
\hline ASEAN & 342.24 & 348.6 & 1,007 \\
\hline Oceania & 24.74 & 323.1 & 12,075 \\
\hline Japan & 124.34 & 3704.6 & 29,794 \\
\hline Korea & 43.66 & 294.5 & 6,749 \\
\hline China & $1,171.71$ & 435.0 & 371 \\
\hline Hong Kong & 5.81 & 96.0 & 16,510 \\
\hline Taiwan & 20.75 & 210.9 & 10,140 \\
\hline
\end{tabular}

Source: Direction of Trade Statistics, IMF 2009 